\title{
Agrotekma
}

Jurnal Agroteknologi dan Ilmu Pertanian

Available online http://ojs.uma.ac.id/index.php/agrotekma

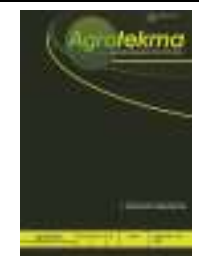

\section{Uji Formulasi Pupuk Hayati Cair dengan Penambahan Bacillus Cereus terhadap Pertumbuhan dan Hasil Tanaman Jagung Manis (Zea Mays Saccharata Sturt.)}

\author{
Liquid Biological Fertilizer Formulations Test with the Addition of \\ Bacillus cereus on Growth and Yield of Sweet Corn (Zea Mays \\ Saccharata Sturt

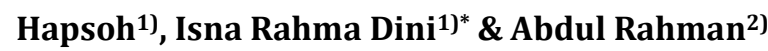 \\ 1) Program Studi Agroteknologi, Fakultas Pertanian, Universitas Riau, Indonesia \\ 2) Program Studi Agroteknologi, Universitas Medan Area, Indonesia \\ Disubmit: Desember 2020; Direview: Juni 2021; Disetujui: Juni 2021; \\ Corresponding Author: isnarahmadini19@gmail.com
}

\begin{abstract}
Abstrak
Penelitian ini bertujuan untuk mengetahui pengaruh pemberian beberapa formulasi pupuk hayati cair dengan penambahan B. cereus dan mendapatkan formulasi terbaik untuk meningkatkan pertumbuhan dan hasil jagung. Percobaan lapangan dilaksanakan di stasiun percobaan Fakultas Pertanian Universitas Riau yang berlokasi di Pekanbaru pada bulan Juli 2018 sampai Oktober 2018. Penelitian dilakukan secara eksperimental dengan menggunakan Rancangan Acak Lengkap (RAL) yang terdiri dari lima perlakuan dengan empat ulangan. Perlakuan yang diuji adalah P1: B. cereus tanpa formulasi, P2: $100 \mathrm{ml}$ B. cereus + $1 \mathrm{l}$ air limbah beras $+1 \mathrm{~g}$ kitin $+100 \mathrm{ml}$ molase, P3: $100 \mathrm{ml}$ B. cereus $+1 \mathrm{l}$ air limbah kelapa $+1 \mathrm{~g}$ kitin + $100 \mathrm{ml}$ molase, P4: $100 \mathrm{ml} \mathrm{B}$. cereus $+1 \mathrm{llimbah}$ cair tahu $+1 \mathrm{~g}$ kitin $+100 \mathrm{ml}$ molase, P5: $100 \mathrm{ml} \mathrm{B}$. cereus +1 l limbah pabrik minyak sawit $+1 \mathrm{~g}$ kitin $+100 \mathrm{ml}$ molase. Parameter yang diamati adalah tinggi tanaman, umur kemunculan bunga betina, umur panen, diameter batang, berat tongkol dengan kelobot jagung, berat tongkol tanpa kulit jagung, panjang tongkol tanpa kulit jagung, diameter tongkol tanpa kulit jagung, jumlah baris biji jagung. Hasil penelitian menunjukkan bahwa semua perlakuan belum mampu meningkatkan respon pertumbuhan dan hasil tanaman jagung dan semua formulasi pupuk hayati $B$. cereus yang diuji belum menemukan formulasi terbaik.
\end{abstract}

Kata Kunci: Jagung; Pupuk Hayati; Bacillus Cereus; Limbah Cair

\begin{abstract}
This study aims to determine the effect of giving several liquid biological fertilizer formulations with the addition of B. cereus and get the best formulation to increase the growth and yield of sweet corn. The field experiment was conducted in the Faculty of Agriculture experiment station, Riau University located in Pekanbaru from July 2018 to October 2018. The research was carried out experimentally using a completely randomized design consisting of five treatments with four replications. The treatments tested were P1: $B$. cereus without formulation, P2: $100 \mathrm{ml} \mathrm{B}$. cereus +1 l wastewater of rice $+1 \mathrm{~g}$ chitin $+100 \mathrm{ml}$ molasses, P3: $100 \mathrm{ml} \mathrm{B.} \mathrm{cereus}+1 \mathrm{l}$ wastewater coconut $+1 \mathrm{~g}$ chitin $+100 \mathrm{ml}$ molasses, P4: $100 \mathrm{ml} \mathrm{B.} \mathrm{cereus}+1 \mathrm{l}$ tofu liquid waste $+1 \mathrm{~g}$ chitin $+100 \mathrm{ml}$ molases, P5: $100 \mathrm{ml} \mathrm{B.} \mathrm{cereus}+1$ l palm oil mill effluent $+1 \mathrm{~g}$ Chitin +100 $\mathrm{ml}$ molasses. The parameters observed were plant height, age of female flower emergence, harvest age, stem diameter, weight of cob with cornhusk, weight of cob without cornhusk, length of cob without cornhusk, diameter of cob without cornhusk, number of rows of corn kernels. The results showed that all treatments have not been able to improve the growth response and yield of corn plants and all formulations of B. cereus biological fertilizer tested have not found the best formulation.
\end{abstract}

Keywords: Sweet Corn; Biological Fertilizer; Bacillus Cereus; Liquid Waste

How to Cite: Hapsoh, Dini, I.R., \& Rahman, A. (2021). Uji Formulasi Pupuk Hayati Cair dengan Penambahan Bacillus Cereus terhadap Pertumbuhan dan Hasil Tanaman Jagung Manis (Zea Mays Saccharata Sturt.), Agrotekma: Jurnal Agroteknologi dan Ilmu Pertanian 5 (2): 132-143. 


\section{PENDAHULUAN}

Jagung merupakan salah satu serealia yang strategis dan bernilai ekonomis serta mempunyai peluang untuk dikembangkan karena kedudukannya sebagai sumber utama karbohidrat setelah beras dan juga sebagai sumber pakan (Purwanto, 2008). Salah satu jenis jagung yang banyak di tanam oleh petani yaitu jagung manis (Zea mays saccharata Sturt.), Menurut Sinaga et al (2010), dalam $100 \mathrm{~g}$ jagung manis terkandung $96 \mathrm{kal}$ energi, $3.5 \mathrm{~g}$ protein, 1 g lemak, 22.8 g karbohidrat, $3.09 \mathrm{mg}$ kalsium, $111 \mathrm{mg}$ fosfor, $0.7 \mathrm{mg}$ besi, $400 \mathrm{SI}$ vitamin $A, 0.15 \mathrm{mg}$ vitamin $B$, dan $12 \mathrm{mg}$ vitamin C.

Jagung manis banyak dikonsumsi karena memiliki rasa yang lebih manis dibandingkan dengan jagung biasa dan umur panennya lebih singkat (Syukur dan Rifianto,2013). Menurut Seprita dan Surtinah (2012) faktor yang dapat merangsang para petani untuk mengembangkan usaha tanaman jagung manis adalah kebutuhan yang meningkat dan harga yang tinggi. Untuk memenuhi kebutuhan pasar dan meningkatkan prosuksi jagung tersebut petani cenderung masih menggunakan pupuk anorganik, tapi penggunaan pupuk anorganik secara terus menerus berdampak negatif bagi tanah dan

lingkungan. Menurut Isnaini (2006), penggunaan pupuk anorganik dalam jangka panjang menyebabkan kadar bahan organik tanah menurun, struktur tanah rusak dan pencemaran lingkungan. Untuk meningkatkan pertumbuhan tanaman jagung manis agar dapat berproduksi secara optimal diperlukan upaya intensifikasi, salah satunya yakni pemanfaatan pupuk hayati dari limbah cair organik. Pupuk hayati adalah pupuk yang mengandung bahan aktif berupa mikrob yang dapat meningkatkan kesuburan dan kesehatan tanah (Kementerian Pertanian, 2009). Salah satu mikrob yang dapat digunakan sebagai pupuk hayati yaitu Bacillus sp. Menurut Comant (2005) Bacillus sp. mempunyai banyak potensi yaitu mampu memproduksi hormon pemacu pertumbuhan berupa indol asam asetat (IAA) dan melarutkan fosfat. Salah satu spesies dari Bacillus sp. yang dapat digunakan sebagai pupuk hayati yaitu Bacillus cereus.

Bakteri B. cereus merupakan bakteri gram positif yang dapat ditemukan di jaringan tanaman mati dan tanah (Huang et al., 2005). Bakteri ini mampu menghasilkan hormon IAA dan memineralisasi bahan organik (Ida et al., 2014). 
Penggunaan Bacillus sp. tanpa formulasi menyebabkan Bacillus sp. tidak dapat bertahan lama, kemampuan sebagai agen hayati maupun sebagai bioaktivator tidak optimal, pemberian dalam bentuk sel bakteri hidup kurang praktis dan kurang efisien (Oktrisna et al., 2017). Formulasi pupuk hayati yang dapat digunakan seperti air kelapa (Palungkun, 1992), limbah pengolahan tahu (Sugiharto, 1994), limbah cair pabrik kelapa sawit (Tsasinul, 2008) dan air cucian beras (Angga, 2016). Limbahlimbah tersebut mengandung karbon organik (karbohidrat) dan nitrogen organik (protein dan asam amino) yang baik digunakan sebagai sumber energi untuk pertumbuhan bakteri Bacillus sp. (Hutabarat et al., 2014). Limbah-limbah tersebut juga dapat dimanfaatkan sebagai pupuk organik yang dapat memperbaiki kesuburan tanah dan meningkatkan pertumbuhan serta produksi tanaman.

Berdasarkan uraian di atas maka penulis telah melakukan penelitian yang berjudul "Uji Formulasi Pupuk Hayati Cair dengan Penambahan Bacillus cereus terhadap Pertumbuhan dan Hasil Tanaman Jagung Manis (Zea mays Saccharata Sturt.)".

Alat-alat yang digunakan dalam penelitian ini adalah gembor, ember, timbangan digital, timbangan analitik, oven, cawan petri, tabung reaksi, batang pengaduk, erlenmeyer, pipet tetes, jarum ose, bunsen, mikro pipet, rak tabung, kulkas, hot plate, autoclave, shaker, laminar atau enkas, pH meter, jangka sorong, baskom, pisau, ayakan, kertas label, cangkul, meteran, polynet, parang, selang, gunting, ajir dan alat tulis.

Penelitian ini dilaksanakan secara eksperimen dengan menggunakan rancangan acak lengkap (RAL) yang terdiri dari lima perlakuan dengan empat ulangan sehingga terdapat 20 unit percobaan. Tiap unit terdiri dari enam tanaman, tiga dari enam tanaman tersebut dijadikan sebagai sampel. Sehingga total jumlah tanaman keseluruhan adalah 120 tanaman dan 60 diantaranya adalah sampel. Parameter yang di amati yaitu respons pertumbuhan (tinggi tanaman, umur muncuk bunga betina, umur panen, diameter batang) dan respos hasil (berat tongkol berkelobot per tanaman, berat tongkol tidak berkelobot per tanaman, panjang tongkol tanpa

\section{METODE PENELITIAN}

Bahan-bahan yang digunakan dalam penelitian ini adalah benih jagung varietas Bonanza F1, polibag ukuran $40 \mathrm{~cm}$ x 50 $\mathrm{cm}$, limbah cair air cucian beras, limbah cair tahu, limbah cair pabrik kelapa sawit, limbah cair air kelapa, isolat B. cereus 
(Hapsoh et al., 2016), alkohol 70\%, aquades, media nutrient agar (NA), nutrient broth (NB), plastik wrap, plastik, tisu gulung, kertas label, spritus, aluminium foil, kitin, molasses, air, pupuk urea, pupuk SP-36, pupuk $\mathrm{KCl}$, pestisida dan tanah sebagai media tanam dari kebun percobaan Fakultas Pertanian Universitas Riau.

Kelobot, diameter tongkol tanpa kelobot, jumlah baris biji per tongkol)

Berikut adalah perlakuan uji formulasi pupuk hayati berbahan aktif bakteri $B$. cereus dalam berbagai limbah organik.

P1 : B. cereus tanpa diformulasi

P2 : $100 \mathrm{ml}$ B.cereus +11 limbah cair air cucian beras $+1 \mathrm{~g}$ kitin +100 $\mathrm{ml}$ molases

P3 : $100 \mathrm{ml} \mathrm{B.} \mathrm{cereus}+11$ limbah cair air kelapa +1 g kitin $+100 \mathrm{ml}$ molases

P4 : $100 \mathrm{ml} \mathrm{B.} \mathrm{cereus}+11$ limbah cair tahu +1 g kitin +100 ml molases

P5 : $100 \mathrm{ml} \mathrm{B.} \mathrm{cereus}+11$ limbah cair pabrik kelapa sawit $+1 \mathrm{~g}$ kitin + $100 \mathrm{ml}$ molases

Data yang diperoleh dianalisis secara statistik dengan menggunakan sidik ragam dengan model linear sebagai berikut:

$$
Y_{i j}=\mu+\tau_{i}+\varepsilon_{i j}
$$

Data yang diperoleh kemudian dilanjutkan dengan uji lanjut BNJ pada taraf 5\%.

\section{HASIL DAN PEMBAHASAN}

\section{Respon Pertumbuhan}

Hasil analisis ragam menunjukkan bahwa semua perlakuan pemberian formulasi pupuk hayati Bacillus cereus berbasis limbah organik cair dan pemberian $B$. cereus tanpa formulasi berpengaruh tidak nyata terhadap tinggi tanaman, umur muncul bunga betina, umur panen dan diameter batang. Hasil uji lanjut respons pertumbuhan tanaman jagung dengan uji BNJ pada taraf 5\% dapat dilihat pada Tabel 1.

Semua perlakuan pemberian formulasi pupuk hayati B. cereus berbasis limbah organik cair pada Tabel 2 memberikan hasil yang berbeda tidak nyata terhadap pemberian B. cereus tanpa formulasi pada semua parameter pengamatan yang diuji (tinggi tanaman, umur muncul bunga betina, umur panen dan diameter batang tanaman jagung). Hal ini disebabkan karena kandungan unsur hara pada semua formulasi pupuk hayati bakteri B. cereus berbasis limbah cair organik memiliki kandungan unsur hara relatif rendah dan konsentrasi yang hampir sama. Hal ini juga telihat pada penelitian Newar et al. (2012), 


\begin{tabular}{ccccc}
\hline Perlakuan & $\begin{array}{c}\text { Tinggi tanaman } \\
(\mathrm{cm})\end{array}$ & $\begin{array}{c}\text { Umur } \\
\text { muncul } \\
\text { bunga } \\
\text { betina } \\
(\mathrm{HST})\end{array}$ & $\begin{array}{c}\text { Umur } \\
\text { panen } \\
(\mathrm{HST})\end{array}$ & $\begin{array}{c}\text { Diameter batang } \\
(\mathrm{mm})\end{array}$ \\
\hline B. cereus tanpa formulasi & $179,78 \mathrm{a}$ & $56,42 \mathrm{a}$ & $74,50 \mathrm{a}$ & $19,41 \mathrm{a}$ \\
B. cereus + air cucian beras & $186,37 \mathrm{a}$ & $55,92 \mathrm{a}$ & $73,50 \mathrm{a}$ & $19,73 \mathrm{a}$ \\
B. cereus + air kelapa & $182,51 \mathrm{a}$ & $56,08 \mathrm{a}$ & $73,75 \mathrm{a}$ & $19,87 \mathrm{a}$ \\
B. cereus + air tahu & $184,23 \mathrm{a}$ & $56,50 \mathrm{a}$ & $74,50 \mathrm{a}$ & $19,56 \mathrm{a}$ \\
B. cereus + LCPKS & $182,11 \mathrm{a}$ & $56,92 \mathrm{a}$ & $74,75 \mathrm{a}$ & $18,78 \mathrm{a}$ \\
\hline
\end{tabular}

Keterangan: Angka-angka yang diikuti oleh huruf kecil yang sama menunjukkan berbeda tidak nyata menurut uji BNJ pada taraf 5\%. LCPKS : Limbah Cair Pabrik Kelapa Sawit.

menunjukkan bahwa pemberian pupuk hayati terhadap tanaman jagung memberikan pengaruh yang tidak nyata terhadap salah satu parameter respons pertumbuhan.

Pemberian formulasi pupuk hayati B. cereus berbasis limbah cair organik belum berpengaruh disebabkan karena belum optimalnya kinerja B. cereus dalam menguraikan bahan organik dan menghasilkan hormon-hormon pertumbuhan. Menurut Wahyuningratri et al. (2017) yang menyatakan bahwa pupuk hayati yang belum dapat meningkatkan kesuburan tanah dikarenakan bakteri yang terkandung di dalam konsentrasi tersebut belum dapat bekerja maksimal dalam merombak dan memfasilitasi asupan unsur hara yang dibutuhkan tanaman.

Pembuatan pupuk hayati harus mempertimbangkan formulasi yang digunakan. Media pembawa harus mengandung komponen penting untuk dan pertumbuhan mikrob yang diinokulasi ke dalamnya (Ambak dan Melling, 2000). Pertumbuhan bakteri dalam pupuk hayati cair sangat dipengaruhi oleh keadaan lingkungan mediumnya. Setiap mikrob akan tumbuh dengan baik di dalam lingkungannya selama kondisinya menguntungkan bagi pertumbuhan dan untuk mempertahankan dirinya. Menurut Asroh (2010), menyatakan bila larutan pupuk hayati diberikan pada tanaman atau permukaan tanah, maka mikrob yang ada belum tentu dapat hidup dan berkembang karena kondisi lingkungan yang mungkin tidak sesuai, antara lain tidak tersedia makanan yang mudah dicerna, temperatur udara yang terlalu tinggi, kelembaban yang kurang, oksigen yang kurang dan menyebabkan mikrob tersebut tidak dapat berkembang. 
Salah satu faktor lingkungan yang berpengaruh terhadap pertumbuhan suatu bakteri adalah $\mathrm{pH}$ (Pelczar dan Chan, 1986). Berdasarkan analisis $\mathrm{pH}$ pupuk hayati cair yang diuji berkisar antara 3,39 sampai 4,90. Kondisi pH tersebut tergolong asam dan kurang sesuai untuk pertumbuhan bakteri B. cereus. Menurut (Raharjo, 2004) bakteri Bacillus sp merupakan bakteri yang tumbuh optimum pada pH netral 6,5-7,5. Apabila pH dalam suatu media tidak optimal maka akan menganggu kerja enzim dan berakibat menganggu pertumbuhan bakteri. Berdasarkan peraturan menteri pertanian nomor 70/Permentan/SR.140/10/2011 baku mutu pH pupuk hayati cair bakteri. tunggal yaitu 5-8. Nilai pH yang rendah pada setiap formulasi yang diuji juga diduga sebagai penyebab terhambatnya pertumbuhan dan aktivitas B. cereus sebagai bioaktivator pupuk hayati.

Menurut Hapsari dan Chalimah (2013) pupuk organik memiliki kandungan hara yang lengkap baik makro dan mikro tetapi jumlahnya memang relatif rendah. Unsur hara makro $\mathrm{C}, \mathrm{H}, \mathrm{O}, \mathrm{N}, \mathrm{P}, \mathrm{K}, \mathrm{Ca}, \mathrm{Mg}, \mathrm{S}$ terutaman $\mathrm{N}$ sangat berpengaruh terhadap peningkatan pertumbuhan tanaman. Menurut Salisbury dan Ross (1995) nitrogen sangat berperan dalam pertumbuhan pada fase vegetatif tanaman dan dibutuhkan dalam jumlah yang relatif banyak dari pada unsur lain. Rerata tinggi tanaman jagung setiap perlakuan pada Tabel 2 belum mencapai tinggi tanaman maksimal jika dibandingkan dengan deskripsi tanaman jagung varietas Bonanza F1. Hasil penelitian Tryana (2019), juga menunjukkan bahwa pertambahan tinggi tanaman padi yang diberi pupuk hayati berbasis limbah organik cair air kelapa, LCPKS, air cucian beras dan air limbah tahu menggunakan konsorsium bakteri selulolitik masih belum mampu memberikan hasil yang maksimal sesuai deskripsi tanaman padi varietas Inpago 9. Diameter batang tanaman jagung pada Tabel 2 juga menunjukkan hasil yang berbeda tidak nyata antar tiap perlakuan. Berdasarkan tabel 1 dapat dilihat bahwa diameter jagung hasil penelitian $(19,41-$ 19,87 $\mathrm{mm}$ ) masih belum menyamai deskripsi tanaman jagung varietas Bonanza F1 (20,00-30,00 mm). Sama halnya dengan pertambahan tinggi tanaman, pembesaran diameter batang juga dipengaruhi oleh unsur hara makro $\mathrm{C}, \mathrm{H}, \mathrm{O}, \mathrm{N}, \mathrm{P}, \mathrm{K}, \mathrm{Ca}, \mathrm{Mg}, \mathrm{S}$ terutama N. Lingga dan Marsono (2003), menyatakan bahwa unsur hara yang terpenuhi akan meningkatkan proses metabolisme dari tanaman, memacu pembelahan dan perpanjangan sel-sel tanaman dan akan 
memacu pertumbuhan tunas-tunas, daun dan pucuk tanaman.

Tabel 2 menunjukkan bahwa umur muncul bunga betina dan umur panen tanaman jagung dengan pemberian pupuk hayati B. cereus yang diformulasikan dalam limbah organik cair dan tanpa formulasi memberikan hasil yang berbeda tidak nyata. Jika dibandingkan dengan deskripsi tanaman jagung manis varietas Bonanza F1 umur muncul bunga betina relatif sama yaitu 55-60 HST, sedangkan umur panen menjadi lebih cepat 5-10 hari dari deskripsi (80-84 HST di dataran medium). Hal ini diduga karena umur muncul bunga betina umur dan umur panen tanaman jagung lebih dipengaruhi oleh faktor genetik (Mangoendidjo, 2003) dan faktor lingkungan tanaman seperti ketinggian tempat penanaman dan unsur hara (Fachruddin, 2000).

Faktor lingkungan yang sangat berpengaruh terhadap umur panen adalah ketinggian tempat penanaman, karena berkaitan dengan iklim dan cuaca. Penelitian ini dilakukan di Kota Pekanbaru yang tergolong dataran rendah. Umur panen menjadi lebih cepat dikarenakan intensitas cahaya pada dataran rendah lebih tinggi dari dataran medium dan dataran tinggi. Jagung merupakan tanaman C4 yang membutuhkan intensitas cahaya tinggi.
Hasil penelitian Alfandi et al. (2013), menyatakan bahwa intensitas cahaya yang lebih tinggi pada dataran rendah membuat tanaman melon yang ditanaman pada dataran rendah menjadi lebih cepat dipanen dibanding pada dataran medium dan dataran tinggi.

\section{Respons Hasil}

Hasil analisis ragam menunjukkan bahwa semua perlakuan pemberian formulasi pupuk hayati B. cereus berbasis limbah organik cair dan pemberian B. cereus tanpa formulasi berpengaruh tidak nyata terhadap berat tongkol berkelobot per tanaman, berat tongkol tidak berkelobot per tanaman, panjang tongkol tanpa kelobot, diameter tongkol tanpa kelobot dan jumlah baris per tongkol tanaman jagung. Hasil uji 


\begin{tabular}{lccccc}
\hline \multicolumn{1}{c}{ Perlakuan } & $\begin{array}{c}\text { Berat tongkol } \\
\text { berkelobot } \\
\text { per tanaman } \\
(\text { gram })\end{array}$ & $\begin{array}{c}\text { Berat } \\
\text { tongkol } \\
\text { tidak } \\
\text { berkelobot } \\
\text { per } \\
\text { tanaman } \\
(\text { gram })\end{array}$ & $\begin{array}{c}\text { Panjang } \\
\text { tongkol } \\
\text { tanpa } \\
\text { kelobot } \\
(\mathrm{cm})\end{array}$ & $\begin{array}{c}\text { Diameter } \\
\text { tongkol } \\
\text { tanpa } \\
\text { kelobot } \\
(\mathrm{mm})\end{array}$ & $\begin{array}{c}\text { Jumlah baris per } \\
\text { tongkol }\end{array}$ \\
\hline B. cereus tanpa formulasi & $277,67 \mathrm{a}$ & $217,08 \mathrm{a}$ & $19,50 \mathrm{a}$ & $45,66 \mathrm{a}$ & $15,33 \mathrm{a}$ \\
B. cereus + air cucian beras & $320,00 \mathrm{a}$ & $250,83 \mathrm{a}$ & $18,80 \mathrm{a}$ & $48,58 \mathrm{a}$ & $16,42 \mathrm{a}$ \\
B. cereus + air kelapa & $294,92 \mathrm{a}$ & $225,75 \mathrm{a}$ & $19,63 \mathrm{a}$ & $48,12 \mathrm{a}$ & $16,00 \mathrm{a}$ \\
B. cereus + air tahu & $296,50 \mathrm{a}$ & $231,00 \mathrm{a}$ & $19,01 \mathrm{a}$ & $48,12 \mathrm{a}$ & $15,75 \mathrm{a}$ \\
B. cereus + LCPKS & $300,50 \mathrm{a}$ & $228,08 \mathrm{a}$ & $19,22 \mathrm{a}$ & $47,55 \mathrm{a}$ & $16,33 \mathrm{a}$ \\
\hline
\end{tabular}

respons hasil tanaman jagung dengan uji

BNJ pada taraf $5 \%$ dapat dilihat pada Tabel 3.

Perlakuan pemberian formulasi pupuk hayati $B$. cereus berbasis limbah organik cair pada Tabel 3 memberikan hasil yang berbeda tidak nyata terhadap permberian $B$. cereus tanpa formulasi pada semua parameter pengamatan yang diuji (berat tongkol berkelobot per tanaman, berat tongkol tidak berkelobot per tanaman, panjang tongkol tanpa kelobot, diameter tongkol tanpa kelobot dan jumlah baris per tongkol tanaman jagung). Hal tersebut diduga karena kandungan unsur hara pada semua pupuk hayati B. cereus berbasis limbah cair organik relatif rendah dengan konsentrasi yang hampir sama.
Memasuki fase generatif, tanaman jagung membutuhkan unsur hara $\mathrm{K}$ dan $\mathrm{P}$ yang relatif lebih banyak. Menurut Prihmantoro dan Indriani (2017), unsur P dibutuhkan tanaman untuk pembentukan adenosin di- dan triphosphate (ADP dan ATP) sebagai energi. Energi dibutuhkan tanaman untuk membentuk bunga serta proses pertumbuhan buah.

Berdasarkan deskripsi tanaman jagung manis varietas Bonanza F1 bobot per tongkol jagung dengan kelobot berpotensi menghasilkan bobot 467-495 g, bobot per tongkol tanpa kelobot 300325 g. Berdasarkan tabel 3 bobot tongkol dengan kelobot paling berat hanya mencapai bobot $320 \mathrm{~g}$ dan bobot tongkol tanpa kelobot paling berat hanya mencapai bobot 250,83 g. Hasil penelitian Marpaung et al. (2018), juga menunjukkan bahwa pemberian formulasi pupuk hayati berbahan aktif 
Bacillus sp. pada tanaman tomat berpengaruh tidak nyata terhadap bobot buah per tanaman pada semua perlakuan yang diuji. Hal ini diduga karena unsur hara yang tersedia di dalam tanah dengan pemberian pupuk hayati $B$. cereus yang diformulasikan dalam beberapa limbah organik cair relatif hampir sama dam pemberian pupuk anorganik sama pada setiap sampel yaitu setengah dosis anjuran.

Menurut Suryana (2008), suatu tanaman akan tumbuh dan berkembang dengan subur apabila unsur hara yang diberikan dapat diserap oleh tanaman dalam bentuk yang sesuai untuk diserap akar serta dalam keadaaan yang cukup. Unsur hara yang cukup akan membantu meningkatkan laju fotosintesis. Menurut Novriani (2010), pembentukan tongkol jagung sangat dipengaruhi oleh unsur P. Unsur $\mathrm{P}$ berperan dalam memacu pembentukan bunga biji dan tongkol jagung. Tersedianya unsur hara $\mathrm{P}$ yang cukup akan menghasilkan energi yang cukup untuk pertumbuhan buah. Sumarmo (1993), mengemukakan bahwa di dalam tanaman, unsur $\mathrm{P}$ membentuk ATP sebagai energi dalam metabolisme tanaman untuk mentranslokasikan fotosintat dari daun ke buah. Semakin banyak fotosintat yang ditranslokasikan pada pembentukan tongkol dan pengisian biji maka bobot tongkol jagung juga akan meningkat.

\section{Berdasarkan Tabel 3 panjang} tongkol dan diameter tongkol tanpa kelobot pada hasil penelitian belum mampu menyamai panjang tongkol dan diameter tongkol sesuai deskripsi tanaman jagung manis varietas Bonanza F1. Berdasarkan deskripsi panjang tongkol jagung varietas Bonanza F1 dapat mencapai 20-22 cm, sedangkan hasil penelitian hanya mencapai 19,01-19,63 $\mathrm{cm}$. Diameter jagung varietas Bonanza F1 dapat mencapai 53,00-55,00 mm, sedangkan hasil penelitian hanya mencapai 45,66-48,58 mm. Menurut Ekowati dan Nasir (2004), diameter tongkol jagung tanpa kelobot akan mempengaruhi jumlah baris biji jagung. Hal ini dapat dilihat pada Tabel 3 dimana jumlah barisan biji jagung semakin banyak seiring dengan pertambahan diameter tongkol jagung tanpa kelobot. Hal ini dikarenakan barisan biji jagung tersebut tumbuh melingkari tongkol jagung sehingga semakin besar diameter tongkol maka semakin besar pula peluang terbentuknya barisan biji pada tongkol.

Kualitas jagung sangat dipengaruhi oleh ketersediaan unsur hara N, P dan K. Arif et al. (2014), menyatakan bahwa unsur $\mathrm{N}$ berperan besar dalam pembentukan biji pada tanaman jagung. 
Unsur $\mathrm{P}$ dibutuhkan tanaman sebagai bahan pembentuk ATP yang dibutuhkan tanaman sebagai energi. Energi digunakan tanaman untuk pembesaran tongkol dan pembentukan biji. Menurut Wahyudin et al. (2017), unsur $P$ sangat berpengaruh dalam proses pertumbuhan dan pembentukan buah. Tersedianya fosfor yang dapat diserap oleh tanaman jagung dalam jumlah yang cukup akan membuat fotosintat yang dialokasikan ke tongkol lebih banyak sehingga diameter dan ukuran buah lebih besar.

Berdasarkan foto hasil penelitian dapat dilihat kualitas tongkol jagung tanpa kelobot kurang memuaskan. Hampir seluruh tongkol tanaman sampel tidak terisi penuh bijinya. Hal ini mungkin disebabkan kekurangan unsur hara. Menurut Efendi (2001), jika tanaman kekurangan $\mathrm{N}$ dan $\mathrm{P}$ akan menyebabkan perkembangan tongkol dan biji tidak normal. Jika kekurangan K maka tongkol yang dihasilkan kecil dan ujungnya meruncing.

\section{SIMPULAN}

Semua perlakuan pemberian formulasi pupuk hayati cair dengan penambahan bakteri $B$. cereus belum dapat meningkatkan respons pertumbuhan dan hasil tanaman jagung manis, dan juga Semua formulasi pupuk hayati cair dengan penambahan bakteri $B$. cereus yang telah diberikan belum menemukan formulasi terbaik.

\section{DAFTAR PUSTAKA}

Alfandi, M. A, R. Sulistyono dan N. Herlina. (2013). Respons pertumbuhan dan hasil lima varietas melon (Cucumis melo L.) pada tiga ketinggian tempat. Jurnal Produksi Tanaman. 1(4) : 342-352.

Ambak, K dan L. Melling. (2000). Management Practices for Sustainable Cultivation of Crop Plants on Tropical Peatland The International Symposium on Tropical Peatlands Bogor. Universitas Gadjah Mada Press. Bogor.

Angga, E.B. (2016). Pengaruh Pemberian Limbah Air Cucian Beras Terhadap Pertumbuhan Tanaman Kangkung Darat (Ipomoea reptans Poir). Skripsi (Tidak dipublikasi). Universitas Pasir Pengaraian. Pasir Pangaraian.

Arif, A, A. N. Sugiharto dan E. Widaryanto. (2014). Pengaruh umur transplanting benih dan pemberian berbagai macam pupuk nitrogen terhadap pertumbuhan dan hasil tanaman jagung manis (Zea mays saccharata Sturt). Jurnal Produksi Tanaman. 2(1): 2-8.

Asroh, A. (2010). Pengaruh takaran pupuk kandang dan interval pemberian pupuk hayati terhadap pertumbuhan dan hasil tanaman jagung manis (Zea mays Saccharata Linn). J. Agronomi. 2 (4): 144148.

Compant, S., B Duffy, J. Nowak., C. Clement and E.A. Barka. (2005). Use of plant growth promoting bacteria for/biocontrol of plant diseases : principles, mechanisme of action and future prospects. Journal Applied and Environmental Microbiology. 7(9) : 4954959.

Efendi, S. (2001). Bercocok Tanam Jagung. Yasa Guna. Jakarta.

Ekowati, D dan M. Nasir. (2011). Pertumbuhan tanaman jagung (Zea mays L.) varietas bisi2 pada pasir reject dan pasir asli di pantai Trisik Kulonprogo . Jurnal Manusia Dan Lingkungan. 18(3): 220-231.

Fachrudin. (2000). Budidaya Tanaman Kacangkacangan. Kanisius. Yogyakarta.

Hapsari, A.Y dan M. Chalimah. (2013). Kualitas dan Kuantitas Kandungan Pupuk Organik Limbah Serasah dengan Inokulum Kotoran Sapi secara Semi Anaerob. Naskah (Tidak dipublikasikan). Universitas Muhammadiyah Surakarta. Surakarta. 
Hapsoh, W dan Dini, I. R.. (2016). Aplikasi Pupuk Organik dengan Teknologi Mikrobiologi Mendukung Pertanian Terpadu Berkelanjutan Berbasis Tanaman Pangan pada Lahan Gambut. Laporan Akhir Hibah Kompetensi LPPM (Tidak dipublikasikan). Universitas Riau. Pekanbaru.

Huang, C., T. Wang., S. Chung dan C. Chen. (2005). Identification of an antifungal chitinase from a potential biocontrol agent, Bacillus cereus. Journal of Biochemistry and Molecular Biology. 38(1) : 82-88.

Hutabarat, R., F. Puspita., M. A. Khoiri. (2014). Uji formulasi pupuk organik cair berbahan aktif Bacillus sp. pada pembibitan utama kelapa sawit (Elaeis guineensis jacq.). Jurnal Online Mahasiswa Fakultas Pertanian. 1:113.

Ida, N. I., J. Benny dan D. S. Aisyah. (2014). Peningkatan produktifitas lahan gambut melalui teknik ameliorasi dan inokulasi mikrob pelarut fosfat. Jurnal Agronomi. 1(1):11-17.

Isnaini, M. (2006). Pertanian Organik. Kreasi Wacana . Yogyakarta.

Kementerian Pertanian. (2009). Peraturan Menteri Pertanian Republik Indonesia Tentang Pupuk Organik, Pupuk Hayati, dan Pembenah Tanah. No 28/Permentan/SR. 130/5/2009. Kementrian Pertanian. Jakarta.

Kementerian Pertanian. (2011). Peraturan Menteri Pertanian Republik Indonesia Tentang Pupuk Organik, Pupuk Hayati, Dan Pembenah Tanah. No 70/Permentan/SR.140/10/2011.

Kementrian Pertanian. Jakarta.

Lingga, P dan Marsono. (2003). Petunjuk Penggunaan Pupuk. Penebar Swadaya. Jakarta.

Mangoendidjo, W. (2003). Dasar-dasar Pemuliaan Tanaman. Kanisius. Yogyakarta.

Marpaung, W.N, F. Puspita dan M. Ali. (2018). Uji beberapa formulasi pupuk hayati berbahan aktif bakteri Bacillus. Sp endofit pada tanaman tomat (Lycopercisum esculentum Mill.). Jurnal Online Mahasiswa Fakultas Pertanian. 5(1): 1-15.

Newar, T. Astina dan Setia Budi. (2012). Penegaruh pemberian pupuk hayati terhadap pertumbuhan dan hasil jagung semi pada tanah podsolik merah kuning. Jurnal Sains Mahasiswa Pertanian. Agronomi Fakultas Pertania UNTAN. 1(1):10-15.

Novriani. (2010). Alternatif pengelolaan unsur hara $\mathrm{P}$ (fosfor) pada budidaya jagung (Zea mays L.). Jurnal Agronobis. 3(2) : 42-48.

Oktrisna, D. (2017). Uji Bakteri Bacillus sp. Endofit diformulasikan dengan Beberapa Bahan
Organik terhadap Tanaman Padi Sawah (Oryza sativa L.). Skripsi (tidak dipublikasikan). Fakultas Pertanian Universitas Riau. Pekanbaru.

Palungkun, R. (1992). Aneka Produk Tanaman Kelapa. Penebar Swadaya. Jakarta.

Pelczar, M. J. dan E. C. S. Chan. (1986). Penterjemah , Ratna Siri Hadioetomo dkk. Dasar-dasar Mikrobiologi 1. Universitas Indonesia Press. Jakarta.

Prihmantoro, H dan Y. H. Indriani. (2017). Petunjuk Praktis Memupuk Tanaman Buah. Penebar Swadaya. Jakarta.

Purwanto, S. (2008). Perkembangan Produksi Dan Kebijakan dalam Peningkatan Produksi Jagung. Direktorat Budi Daya Serealia, Direktorat Jenderal Tanaman Pangan. Bogor.

Raharjo B. (2004). Penapisan Rhizobakteri Tahan Tembaga (Cu) dan Mampu Mensintesis IAA dari Rizosfer Kedelai ( Glicyne max L.). Tesis (tidak dipublikasikan). Institut Teknologi Bandung. Bandung.

Salisbury, F. B. dan C. W. Ross. (1995). Fisiologi Tumbuhan. Terjemahan Dian Rukmana dan Sumayono. Institut Teknologi Bandung. Bandung.

Sinaga, J. dan Rosmimi. (2010). Pertumbuhan dan produksi jagung manis (Zea mays L. saccharata) pada tanah gambut yang diaplikasikan amelioran dregs dan fosfat alam. Sagu. 9(2): 20 - 27.

Sugiharto. (1994). Dasar-dasar Pengolahan Air Limbah. Penerbit Universitas. Indonesia. Jakarta.

Sumarmo, M. S. (1993). Sistem Unsur Hara Tanaman. Universitas Brawijaya Malang. Malang.

Suryana. (2008). Pengaruh naungan dan dosis pupuk kotoran ayam terhadap pertumbuhan dan hasil paprika ( Capsicum annuum ). Jurnal Agricolvol. 1(1): 22-28.

Syukur, M dan Rifianto. (2013). Jagung Manis. Penebar Swadaya. Jakarta.

Tryana, S. (2019). Aplikasi Formulasi Pupuk Hayati Konsorsium Bakteri Selulolitik Berbasis Limbah Cair Organik terhadap Pertumbuhan dan Hasil Tanaman Padi Gogo (Oryza sativa L.). Skripsi (Tidak dipublikasikan). Universitas Riau. Pekanbaru.

Tsasinul, A. (2008). Pengaruh Pemanfaatan Limbah Cair Pabrik Kelapa Sawit Sebagai Unsur Hara Tanaman Kelapa Sawit. Skripsi (Tidak dipublikasikan). Institut Pertanian Bogor. Bogor.

Wahyudin, A, B. N. Fitriatin, F. Y. Wicaksono, Ruminta dan A. Rahadiyan. (2017). Responss tanaman jagung (Zea mays L.) akibat pemberian pupuk fosfat dan waktu 
aplikasi pupuk hayati mikrob pelarut fosfat pada ultisol Jatinangor. Jurnal Kultivasi. 16(1): 246-253.

Wahyuningratri, A., N. Aini., dan S. Heddy. (2017).

Pengaruh konsentrasi dan frekuensi pemberian pupuk hayati terhadap pertumbuhan dan hasil cabai besar (Capsicum annum L.). Jurnal Produksi Tanaman. 5(1): 84-91. 